\title{
Sweet Sorghum: Salt Tolerance and High Biomass Sugar Crop
}

\author{
A. Almodares ${ }^{1}$, M. R. Hadi ${ }^{2}$ and Z. Akhavan Kharazian ${ }^{1}$ \\ ${ }^{1}$ Department of Biology, University of Isfahan, \\ ${ }^{2}$ Department of Biology, Sciences and Research Branch of Fars, \\ Islamic Azad University, \\ Iran
}

\section{Introduction}

Soil salinity is one of the main problems for plant growth in agriculture, especially in countries where crops should be irrigated (Ahloowalia et al., 2004). Soil salinity has been considered a limiting factor to crop production in arid and semi arid regions of the world (Munns, 2002). Saline soils are estimated about $5-10 \%$ of the world's arable land (Szabolcs, 1994), and the area affected by salinity is increasing steadily (Ghassemi et al., 1995). Saltaffected soils are distributed throughout the world and no continent is free from the problem (Brandy and Weil, 2002). Globally, a total land area of 831 million hectares is saltaffected (Kinfemichael \& Melkamu, 2008; FAO, 2000). However, soil salt accumulation can change with time and place, as a function of soil management, water quality (Almodares \& Sharif, 2005), irrigation method, and the weather conditions. Salt accumulation is mainly related to a dry climate, salt-rich parent materials of soil formation, insufficient drainage and saline groundwater or irrigation water (Almodares et al., 2008a). Salts in soils are chlorides and sulfates of sodium, calcium, magnesium, and potassium that among them sodium chloride has the highest negative effect on the plant growth and development. Salinity causes slow seed germination, sudden wilting, and reduce growth, marginal burn on leaves, leaf yellowing, leaf fall, restricted root development, and finally death of plants. The inhibitory effects of salinity on plant growth include: (1) ion toxicity (2) osmotic influence (3) nutritional imbalance leading to reduction in photosynthetic efficiency and other physiological disorders. Among agricultural crops, sorghum (Sorghum bicolor L. Moench) is naturally drought and salt-tolerant crop that can produce high biomass yields with low input. Also, it can thrive in places that do not support corn, sugarcane and other food crops. In addition, sweet sorghum has potential uses (six F) such as: food (grain), feed (grain and biomass), fuel (ethanol production), fiber (paper), fermentation (methane production) and fertilizer (utilization of organic byproducts), thus it is an important crop in semi-aired and aired regions of the world. Sorghum is grown on approximately 44 million hectares in 99 countries (ICRISAT, 2009). An estimation of the world-wide tonnage produced in 2007-2008 is shown in Table 1. The increasing cost of energy and deplete oil and gas reserves has created a need for alternative fuels from renewable sources. The consumption of biofule may reduce greenhouse gases. Also it can be replaced with lead tetraethyl or MTBE (Methyl tert-butyl ether) that are air and underground water pollutants, 
respectively (Almodares \& Hadi, 2009). Plants are the best choice for biofule global demands. Currently, ethanol production is based on sugar or starch of crops such as sorghum, corn, sugarcane, wheat and etc. In comparison with other crops, carbohydrate content of sweet sorghum stalk and its grain starch is similar to sugarcane and corn, respectively but its water and fertilizer requirements are much lower than both sugarcane and corn. Thus, in many tropical and temperate countries where sugarcane and corn cannot be grown, a growing interest is being focused on the potential of sweet sorghum to produce bioethanol feed stock (Almodares et al., 2006, 2008d). Sweet sorghum biomass has rich fermentable sugars such as sucrose, glucose, and fructose so it is an excellent raw material for fermentative production (Almodares et al., 2008d). The total soluble sugars can be increase in sweet sorghum with increasing salinity level and sucrose content could be an indicator for its salt tolerance. (2008b). Salt-stressed sorghum plants additionally accumulate organic solutes, like proline, glycinabetaine, sugars, etc. (Lacerda et al., 2001). These organic solutes may contribute to osmotic adjustment, protecting cell structure and function, and/or may serve as metabolic or energetic reserve (Hasegawa et al., 2000). Inorganic and organic solutes concentrations maintained during salt stress, therefore, they may be important during the salt stress recovery period (Pardossi et al., 1998). Since sweet sorghum is more salt tolerant than sugarcane and corn which currently are the main sources of bioethanol production. Therefore, it is suggested to plant sweet sorghum for biofule production in hot and dry countries to solve problems such as increasing the octane of gasoline and to reduce greenhouse gases.

\begin{tabular}{|l|c|c|}
\hline \multicolumn{1}{|c|}{ Country } & $\begin{array}{c}\text { Production } \\
\text { (tonnes x 1000) }\end{array}$ & $\begin{array}{c}\text { \%of } \\
\text { Total }\end{array}$ \\
\hline United States & 12,827 & 20 \\
\hline Nigeria & 10,000 & 16 \\
\hline India & 7,780 & 12 \\
\hline Mexico & 6,100 & 10 \\
\hline Sudan & 4,500 & 7 \\
\hline Ethiopia & 3,230 & 5 \\
\hline Argentina & 2,900 & 5 \\
\hline Australia & 2,691 & 4 \\
\hline China & 1,900 & 3 \\
\hline Burkina Faso & 1,800 & 3 \\
\hline Brazil & 1,700 & 3 \\
\hline Other countries & 6,880 & 12 \\
\hline Total & $\mathbf{6 2 , 3 0 8}$ & 100 \\
\hline
\end{tabular}

Table 1. World Sorghum Production 2007-2008 (Quotation from U.S. Grain Council, 2008).

\section{Salinity problem and ways to resolve it}

About $7 \%$ of the world's total land area is affected by salt, as is a similar percentage of its arable land (Ghassemi et al., 1995). Salinity is often accompanied by other soil properties, such as sodicity and alkalinity, which exert their own specific effects on plant growth. There 
are three ways in which salinity stress of crops could be reduced; 1 - Farm management practices; 2- Screening; 3- Breeding which will be discussed in the followings:

\subsection{Farm management practices}

All irrigation waters contain some dissolved salts. Thus, soil salinization may be expected by crop irrigation. Removal of salts from the root zone may be the most effective way to eliminate the effects of salinity. However, it is expensive and requires good drainage system. It is not always possible to carry out this operation; thereby a number of other different ways could be considered such as:

a. Soil Reclamation; in a case $\mathrm{Na}$ ions are the major cause of soil salinity, it may be replaced with $\mathrm{Ca}$ ions by adding of gypsum (calcium sulfate) to the soil.

b. Reduction of the salt from seed germination zone; Seed germination and seedling establishment are the most sensitive stages to salinity. A number of approaches have been used. 1) Removal of surface soil (Qureshi et al., 2003). 2) Pre-sowing irrigation with good quality water (Goyal et al., 1999). 3) Planting seed on the ridge shoulders rather than on the ridge top of the furrow. 4) Planting in a pre-flooded field with good quality water (Goyal et al., 1999).

c. Reducing soil salinity by adding mulch, organic matter or deep tillage to the soil.

\subsection{Screening}

Salinity and waterlogging co-exist in the lower reaches of several river basins throughout the world, affecting agricultural production and the livelihoods of the affected communities (Wichelns and Oster, 2006). Efforts being made to overcome salinity and waterlogging problems by consist of engineering solutions such as installation of a drainage system to manage the drainage effluent generated by irrigated agriculture. This is a long term strategy; however drainage installation is expensive. The areas under salt-affected and waterlogged soils are expanding because of inappropriate on-farm water and soil management. Selection and cultivation of high-yielding salt-tolerant varieties of different crops is a potential interim strategy to fulfill the needs of the communities relying on these soils for their livelihoods (Ayers and Westcot, 1989). Many crops show intraspecific variation in response to salinity. Sorghum is moderately salt-tolerant. Generally, substantial genotypic differences exist among sorghum cultivars in response to salinity stress (Sunseri et al., 2002; Netondo et al., 2004).

\subsubsection{Screening methods based on growth or yield}

Screening large numbers of genotypes for salinity tolerance in the field is difficult, due to spatial heterogeneity of soil chemical and physical properties, and to seasonal rainfall distribution. Frequently, short-term growth experiments have revealed little difference between genotypes that differ in long-term biomass production or yield. Many short-term growth experiments measuring whole shoot biomass revealed little difference between plant genotypes in their response to salinity, even between those known to differ in long-term biomass production or yield (Rivelli et al., 2002). Longer-term experiments are necessary to detect genotypic differences in the effects of salinity on growth: it is necessary to expose plants to salinity for at least two weeks, and sometimes several months (Munns et al., 1995). Even with rice, a fast growing and salt sensitive species, it is necessary to grow plants for 
several weeks to be confident of obtaining reproducible differences in salinity tolerance between genotypes (Zhu et al., 2001).

\subsubsection{Screening methods based on damage or tolerance to very high salinity levels}

Techniques that can handle large numbers of genotypes include: germination or plant survival in high salinity, leaf injury as measured by membrane damage (leakage of ions from leaf discs), premature loss of chlorophyll (using a hand-held meter), or damage to the photosynthetic apparatus (using chlorophyll fluorescence). These methods can identify genotypes able to germinate, or survive, in very high salinities (over $200 \mathrm{mM} \mathrm{NaCl}$ ), but do not discriminate between genotypes in their ability to tolerate the low or moderate salinities typical of many saline fields $(50-100 \mathrm{mM} \mathrm{NaCl})$. A major limitation to the use of injury or survival to identify salt-tolerant germplasm arises when the cause of injury is not known.

\subsubsection{Screening methods based on physiological mechanisms}

Because of the complex nature of salinity tolerance, as well as the difficulties in maintaining long-term growth experiments, trait-based selection criteria are recommended for screening techniques (Noble and Rogers, 1992). Traits used for screening germplasm for salinity tolerance have included $\mathrm{Na}+$ exclusion, $\mathrm{K}^{+} / \mathrm{Na}^{+}$discrimination (Asch et al., 2000) and $\mathrm{Cl}^{-}$ exclusion (Rogers and Noble, 1992). The relationship between salinity tolerance and $\mathrm{K}^{+} / \mathrm{Na}^{+}$ discrimination was also considered, because $\mathrm{K}^{+} / \mathrm{Na}^{+}$rather than $\mathrm{Na}^{+}$alone has been used as an index of salinity tolerance for cultivar comparisons in wheat (Chhipa and Lal, 1995) and rice (Zhu et al., 2001). One of the mechanism of salinity tolerance that could be considered was tissue tolerance of high internal $\mathrm{Na}^{+}$concentrations. Tissue tolerance cannot be measured directly, and is difficult to quantify. Yet it is clearly important; overexpression of vacuolar $\mathrm{Na}^{+} / \mathrm{H}^{+}$antiporter that sequesters $\mathrm{Na}^{+}$in vacuoles improved the salinity tolerance of Arabidopsis, tomato and brassica (Aharon et al., 2003).

\subsection{Breeding}

Breeding programs for new varieties of sweet sorghum suited to semi arid tropics, temperate areas with rainy summer, Mediterranean areas with dry summer and soil salinity, are under development (Cosentino, 1996).

\section{Why sweet sorghum?}

\subsection{Agricultural advantages}

\subsubsection{Salt tolerance}

Sorghum is characterized as moderately tolerant to salinity (Almodares and Sharif, 2005; Almodares and Sharif, 2007). Salinity reduces sorghum growth and biomass production . Salinity greatly reduced sorghum growth and this effect was more pronounced at $250 \mathrm{mM}$ than at $125 \mathrm{mM} \mathrm{NaCI}$ (Ibrahim, 2004). However it was reported that sorghum growth was significantly reduced at all salinity levels from 50 to $150 \mathrm{mM}$ (El-Sayed et al., 1994). Imposition of salt stress resulted in decreases in the percentage of seeds germinated (Almodares et al., 2007), although the strongest decline in germination occurred at the highest salt concentration (Table 2). Nevertheless, the development of high-yielding salinity tolerant sorghums is the best option to increase the productivity in soils (Igartua et al. 1994). Similarly, Gill et al. (2003) observed a great reduction in germination rate due to salt stress, in sorghum seeds at $37{ }^{\circ} \mathrm{C}$ in $\mathrm{NaCl}(-1.86 \mathrm{MPa})$. 
Relative percent germination(\%)in osmotic potential (Mpa)created by $\mathrm{NaCl}$

\begin{tabular}{lllllll} 
Cultivars & -0.4 & -0.8 & -1.2 & -1.6 & -2.0 & -2 \\
\hline IS 9639 & $48 \mathrm{~d}$ & $4 \mathrm{e}$ & $0 \mathrm{f}$ & $0 \mathrm{e}$ & $0 \mathrm{~b}$ & $0 \mathrm{~b}$ \\
Sova & $87.5 \mathrm{abc}$ & $70 \mathrm{abc}$ & $30 \mathrm{de}$ & $12.5 \mathrm{de}$ & $7.5 \mathrm{~b}$ & $7.5 \mathrm{~b}$ \\
Vespa & $80 \mathrm{abc}$ & $51.5 \mathrm{bcd}$ & $17 \mathrm{ef}$ & $3 \mathrm{de}$ & $0 \mathrm{~b}$ & $0 \mathrm{~b}$ \\
S 35 & $83 \mathrm{abc}$ & $74.5 \mathrm{ab}$ & $54.5 \mathrm{bcd}$ & $8.5 \mathrm{de}$ & $3 \mathrm{~b}$ & $3 \mathrm{~b}$ \\
M 81E & $73 \mathrm{bc}$ & $85.5 \mathrm{a}$ & $36 \mathrm{de}$ & $0 \mathrm{e}$ & $0 \mathrm{~b}$ & $0 \mathrm{~b}$ \\
IS 19273 & $81 \mathrm{abc}$ & $46.5 \mathrm{~cd}$ & $29.5 \mathrm{de}$ & $0 \mathrm{e}$ & $0 \mathrm{~b}$ & $0 \mathrm{~b}$ \\
IS 6936 & $87 \mathrm{abc}$ & $77 \mathrm{a}$ & $33.5 \mathrm{de}$ & $5 \mathrm{de}$ & $0 \mathrm{~b}$ & $0 \mathrm{~b}$ \\
MN 1500 & $72.5 \mathrm{bc}$ & $47.5 \mathrm{~cd}$ & $20 \mathrm{ef}$ & $2.5 \mathrm{de}$ & $0 \mathrm{~b}$ & $0 \mathrm{~b}$ \\
Sumac & $100 \mathrm{a}$ & $62.5 \mathrm{abcd}$ & $67.5 \mathrm{abc}$ & $47.5 \mathrm{ab}$ & $45 \mathrm{a}$ & $45 \mathrm{a}$ \\
IS 686 & $63 \mathrm{~cd}$ & $40 \mathrm{~d}$ & $66 \mathrm{abc}$ & $14 \mathrm{de}$ & $0 \mathrm{~b}$ & $0 \mathrm{~b}$ \\
SSV 108 & $87.5 \mathrm{abc}$ & $85 \mathrm{a}$ & $72.5 \mathrm{ab}$ & $25 \mathrm{bcde}$ & $5 \mathrm{~b}$ & $5 \mathrm{~b}$ \\
Roce & $87 \mathrm{abc}$ & $74 \mathrm{ab}$ & $89.5 \mathrm{a}$ & $42 \mathrm{abc}$ & $34.5 \mathrm{a}$ & $34.5 \mathrm{a}$ \\
Sofrah & $89.5 \mathrm{ab}$ & $84 \mathrm{a}$ & $53 \mathrm{bcd}$ & $23.5 \mathrm{bcde}$ & $5.5 \mathrm{~b}$ & $5.5 \mathrm{~b}$ \\
Satiro & $95 \mathrm{ab}$ & $42 \mathrm{~d}$ & $32 \mathrm{de}$ & $0 \mathrm{e}$ & $5 \mathrm{~b}$ & $5 \mathrm{~b}$ \\
IS 2325 & $89.5 \mathrm{ab}$ & $77 \mathrm{a}$ & $46 \mathrm{~cd}$ & $28 \mathrm{bcd}$ & $0 \mathrm{~b}$ & $0 \mathrm{~b}$ \\
E 36-1 & $62.5 \mathrm{~cd}$ & $42.5 \mathrm{~d}$ & $30 \mathrm{de}$ & $2.5 \mathrm{de}$ & $0 \mathrm{~b}$ & $0 \mathrm{~b}$ \\
IS 6973 & $85.5 \mathrm{abc}$ & $74.5 \mathrm{ab}$ & $71.5 \mathrm{ab}$ & $20 \mathrm{cde}$ & $23 \mathrm{ab}$ & $23 \mathrm{ab}$ \\
SSV84 & $94.5 \mathrm{ab}$ & $84.5 \mathrm{a}$ & $64 \mathrm{bc}$ & $64 \mathrm{a}$ & $0 \mathrm{~b}$ & $0 \mathrm{~b}$ \\
\hline
\end{tabular}

Values of letters $(a, b, \ldots)$ within each column followed by the same letter are not significantly different at $5 \%$ level, using Duncan multiple rang test.

Table 2. Effects of salinity on relative percent germination in 18 sweet sorghum cultivars (Quotation from Samadani et al., 1994).

According to Prado et al. (2000), the decrease in germination may be ascribed to an apparent osmotic 'dormancy' developed under saline stress conditions, which may represent an adaptive strategy to prevent germination under stressful environment. Germination time delayed with the increase in saline stress and root growth was more sensitive to salt stress than was germination (Gill et al., 2003). It seems that grain weight is related to salt tolerance in sweet sorghum. It showed that higher total seedling dry weight was obtained with larger 
seed size in 18 sweet sorghum cultivars under salt stress (Table 3 and Fig. 1). The presence of large genotypic variation for tolerance to salinity is reported in sorghum (Maiti et al, 1994). Sorghum seems to offer a good potential for selection, as intraspecific variation for germination under saline conditions (Table 2) or in the presence of other osmotic agents that has already been reported. Selection of salt tolerant cultivars is one of the most effective methods to increase the productivity of salinity in soils (Ali et al., 2004). By using these salt tolerant plants in breeding they produced progranuned an improved plant having higher chlorophyll concentration, more leaf area, early and better yield potential etc. The advancement of salinity tolerance during the early stages of sorghum growth been successfully accomplished through selection.

\begin{tabular}{lcc}
\hline \multicolumn{1}{c}{ Cultivar } & $\begin{array}{c}\text { Thousand Grain } \\
\text { Weight }(\mathrm{g})\end{array}$ & $\begin{array}{c}\text { Total Seedling Fresh Weight } \\
(\mathrm{mg} / 20 \mathrm{grain})\end{array}$ \\
\hline IS 9639 & 18.75 & 79 \\
Sova & 19.77 & 197 \\
Vespa & 15.35 & 180 \\
S 35 & 30.63 & 349 \\
M 81E & 14.59 & 127 \\
IS 19273 & 27.69 & 267 \\
IS 6936 & 34.33 & 418 \\
MN 1500 & 24.59 & 192 \\
Sumac & 12.63 & 81 \\
IS 686 & 17.15 & 194 \\
SSV 108 & 39.61 & 381 \\
Roce & 17.16 & 159 \\
Sofrah & 16.68 & 170 \\
Satiro & 15.21 & 246 \\
IS 2325 & 31.35 & 335 \\
E 36-1 & 33.33 & 434 \\
IS 6973 & 38.52 & 344 \\
SSV84 & 40.05 & 524 \\
SS & &
\end{tabular}

Table 3. Thousand Grain Weight (g) of 18 sweet sorghum cultivars and Total Seedlings Fresh weight (mg/20 grain) grown in osmotic potential (-0.4 Mpa) of $\mathrm{NaCl}$ after 12 day treatment (Quotation from Samadani et al., 1994). 
Genotypes possessing salt tolerance characteristics will help in boosting up plants production in salt-affected soils (Ali et al., 2004). Azhar and McNeilly (1988) found that, for salinity tolerance of young sorghum seedlings, both additive and dominant effects were involved, the latter being of greater importance. Attempts have been made to evaluate salt tolerance at the germination and emergence stages in sorghum (Igartua et al., 1994). In fact, the variation in whole-plant biomass responses to salinity was considered to provide the best means of initial selection of salinity tolerant genotypes (Krishnamurthy et al, 2007). The presence of large genotypic variation for tolerance to salinity reported in sorghum (Krislmamurthy et al., 2007). There are large genotypic variations for tolerance to salinity in sorghum (Table 4). The other possible solution could be either using physical or biological practice (Gupta and Minhas, 1993). Sudhir and Murthy (2004) reviewed both multiple inhibitory effects of salt stress on photosynthesis and possible salt stress tolerance mechanisms in plants. Salinity reduced relative growth rates and increased soluble carbohydrates, especially in the leaves of salt sensitive genotype (Lacerda et al., 2005). In addition salt-stressed sorghum plants additionally accumulate organic solutes, like proline, glycinabetaine, sugars, etc. (Lacerda et al., 2001). The total soluble sugar increased in sorghum sap with increasing salinity level (Ibrahim, 2004; Almodares et al., 2008a). Sucrose content of plant parts is an indicator of salt tolerance (Juan et al., 2005). The imposition of strong water or salt stresses in sorghum has been demonstrated to be accompanied to an increase in the sugar levels of embryos, which may help in osmoregulation under stress conditions (Gill et al., 2003). The fructose level is always higher than glucose and sucrose levels in response to various salinity treatments (Gill et al., 2001; Almodares et al., 2008a).

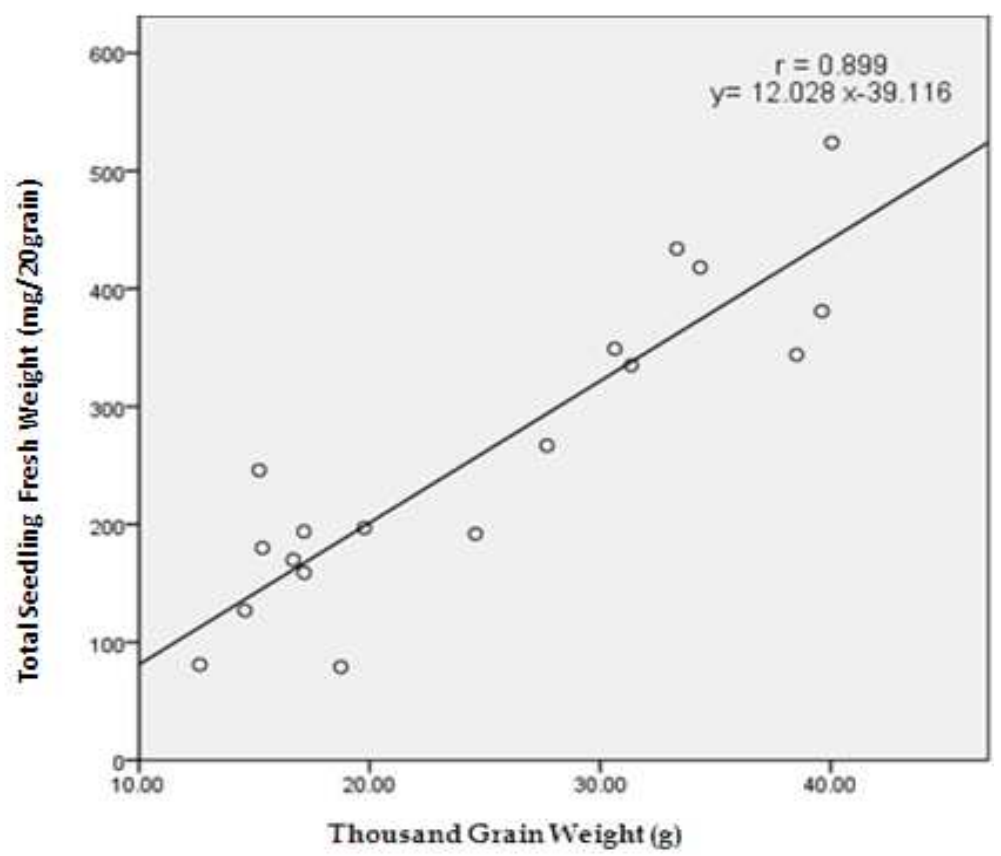

Fig. 1. Correlation between total seedling fresh weight and thousand grain weight in sweet sorghum (Quotation from Samadani et al., 1994). 


\subsubsection{Mechanisms of salt tolerance in crops}

Sodium is the major cation that accumulated in roots and stems as salinity increased (Meneguzzo et al., 2000). It is evident that salt tolerance is associated with low uptake of $\mathrm{Na}^{+}$(Santa-Maria and Epstein, 2001), partial exclusion (Colmer et al., 1995) and compartmentalization of salt in the cell and within the plant (Ashraf, 1994). The preferential accumulation in roots over shoots may be interpreted as a mechanism of tolerance in at least two ways.

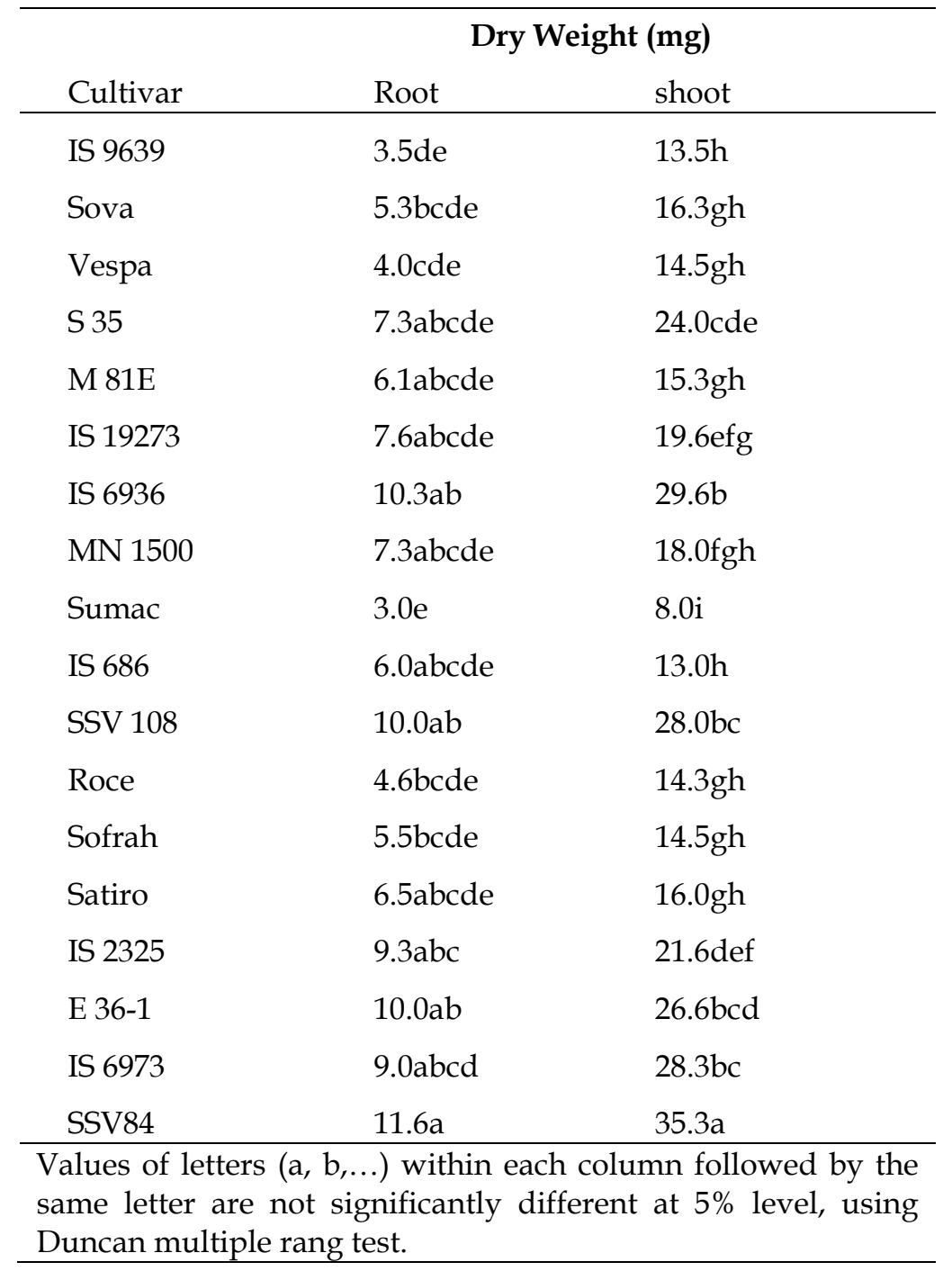

Table 4. Root and shoot dry weight of 18 sweet sorghum cultivars that grown in osmotic potential (-0.4 Mpa) of $\mathrm{NaCl}$ through 12 day (Quotation from Samadani et al., 1994). 
First, maintenance of a substantial potential for osmotic water uptake into the roots and second, restricting the spread of $\mathrm{Na}^{+}$to shoots (Renault et al., 2001). High $\mathrm{Na}^{+}$levels in the external medium greatly reduce the physicochemical activity of dissolved calcium and may thus displace $\mathrm{Ca}^{2+}$ from the plasma membrane of root cells. In turn, displacement of $\mathrm{Ca}^{2+}$ from root membranes by $\mathrm{Na}^{+}$affects $\mathrm{Na} / \mathrm{K}$ uptake selectivity in favor of sodium. A low $\mathrm{Ca}^{2+}$ concentration under saline conditions may severely affect the functions of membranes as barriers to ion loss from cells (Boursier and Läuchli, 1990). Various organic and inorganic solutes such as $\mathrm{K}^{+}, \mathrm{Na}^{+}, \mathrm{Cl}^{-}$, proline, and glycinebetaine have been reported to contribute to such osmotic adjustment (Saneoka et al., 2001). Salinity inhibits the accumulation of $\mathrm{K}^{+}$and $\mathrm{Ca}^{2+}$ in roots and stems. The negative effect of $\mathrm{NaCl}$ on the allocation of $\mathrm{K}^{+}, \mathrm{Ca}^{2+}$, and $\mathrm{Mg}^{2+}$ to the leaf tissues may contribute to their deficiency and the accompanying metabolic perturbations. The altered ion and water relations have a severe impact on the photosynthetic performance of the plant (Netondo et al., 2004). Many plants accumulate high levels of free proline in response to osmotic stress. This amino acid is widely believed to function as a protector or stabilizer of enzymes or membrane structures that are sensitive to dehydration or ionically induced damage. The salt stress caused increases in proline levels. Several investigations have shown that, besides other solutes, the level of free amino acids, especially proline, increases during adaptation to various environmental stresses. Plant salt tolerance has been generally studied in relation to regulatory mechanisms of ionic and osmotic homeostasis (Ashraf and Harris, 2004). In addition to ionic and osmotic components, salt stress, like other abiotic stress, also leads to oxidative stress through an increase in Reactive Oxygen Species (ROS), such as superoxide (02-), hydrogen peroxide $\left(\mathrm{H}_{2} \mathrm{O}_{2}\right)$ and hydroxyl radicals $(\mathrm{OH})$ (Mittler, 2002). It has been reported that most abiotic stress including NaCI salt stress impose injury in plants by osmotic stress, ionic stress and generating reactive oxygen species (Shalata and Tal, 1998). During oxidative stress, the excess production of Reactive Oxygen Species (ROS) causes membrane damage that eventually leads to cell death. For protection against ROS, plants contain antioxidant enzymes such as superoxide dismutase (SOD), catalase (CAT), ascorbate peroxidase (APX), guaiacol peroxidase (GPX) and Glutathione Reductase (GR) or as well as a wide array of nonenzymatic antioxidants (Blokhina et al., 2003). SOD is the major 02- scavenger and its enzymatic action results in $\mathrm{H} 202$ and $\mathrm{O} 2$ formation. The H202 produced is then scavenged by CAT and several classes of peroxidases. CAT, which is found in peroxisomes, cytosol and mitochondria, dismutates $\mathrm{H}_{2} \mathrm{O}_{2}$ to $\mathrm{H}_{2} \mathrm{O}$ and $\mathrm{O}_{2}$ (McKersie and Leshem, 1994). Sorghum is a salt tolerant plant therefore it seems that it uses some of the above mechanisms for its adaptation to salt and drought stress.

\subsubsection{High yield in drought and salinity regions}

Sorghum is the 5th grain crop grown based on tonnage, after maize, wheat, rice, and barley (CGIAR website, 2009) with a high yield of biomass (Almodares et al., 1994; Gardner et al., 1994). Sweet sorghum like grain sorghum produces grain 3-7 t/ha (Almodares et al., 2008e). But the essence of sweet sorghum is not from its seed, but from its stalk, which contains high sugar content (Almodares et al., 2008c). In general, it can produce stalk 54-69 t/ha (Almodares et al., 2008d). 


\begin{tabular}{|c|c|c|c|c|}
\hline Genotypes & Stem Yield (t ha-1) & Brix $(\%)$ & Sucrose (\%) & Purity (\%) \\
\hline \multicolumn{5}{|l|}{ Cultivars: } \\
\hline Roce & 39.14 & 21.96 & 14.39 & 66.71 \\
\hline Vespa & 84.53 & 20.99 & 13.05 & 74.59 \\
\hline Brandes & 77.14 & 18.72 & 8.92 & 46.39 \\
\hline MN1500 & 83.71 & 20.71 & 12.00 & 57.59 \\
\hline E36-1 & 48.00 & 18.26 & 13.41 & 76.02 \\
\hline Soave & 61.57 & 20.73 & 13.46 & 65.00 \\
\hline M81-E & 103.57 & 16.01 & 10.26 & 65.10 \\
\hline Sumac & 44.43 & 21.12 & 12.85 & 60.10 \\
\hline Sofrah & 85.57 & 19.63 & 12.61 & 64.05 \\
\hline SSV-108 & 62.85 & 22.25 & 13.97 & 62.26 \\
\hline SSV-94 & 70.14 & 20.64 & 11.75 & 57.12 \\
\hline SSV-96 & 62.00 & 22.54 & 13.71 & 60.10 \\
\hline Theis & 100.14 & 19.10 & 7.26 & 37.59 \\
\hline Foralco & 97.71 & 20.40 & 12.64 & 60.83 \\
\hline Rio & 95.00 & 22.36 & 16.06 & 71.31 \\
\hline S-35 & 58.43 & 19.78 & 11.58 & 58.75 \\
\hline Turno & 39.86 & 11.16 & 6.00 & 35.86 \\
\hline Satiro & 27.86 & 17.16 & 10.33 & 60.02 \\
\hline Wary & 126.42 & 15.84 & 7.85 & 49.40 \\
\hline \multicolumn{5}{|l|}{ Lines: } \\
\hline IS 686 & 61.43 & 16.54 & 9.00 & 54.39 \\
\hline IS 16054 & 51.85 & 21.07 & 11.73 & 55.83 \\
\hline IS 18154 & 42.14 & 19.04 & 12.71 & 66.71 \\
\hline IS 6962 & 43.00 & 23.01 & 13.61 & 58.85 \\
\hline IS 9639 & 54.00 & 21.77 & 14.31 & 65.23 \\
\hline IS 2325 & 59.57 & 20.70 & 14.28 & 60.18 \\
\hline IS 6973 & 33.43 & 22.85 & 14.21 & 61.88 \\
\hline IS 4546 & 56.43 & 22.03 & 13.05 & 60.12 \\
\hline IS 19273 & 46.28 & 20.29 & 15.04 & 73.69 \\
\hline IS 4354 & 33.86 & 17.66 & 9.80 & 55.28 \\
\hline \multicolumn{5}{|l|}{ Hybrids: } \\
\hline A1 $x$ IS 6973 & 83.28 & 16.46 & 9.53 & 57.17 \\
\hline A13 x IS 1273 & 97.00 & 21.18 & 14.26 & 66.78 \\
\hline A1 x IS 19261 & 88.13 & 18.69 & 11.82 & 63.04 \\
\hline A1 x IS 14446 & 87.13 & 16.51 & 10.51 & 62.89 \\
\hline A45 x IS 14446 & 124.13 & 17.95 & 13.36 & 74.06 \\
\hline A1 x IS 19273 & 128.85 & 17.82 & 13.00 & 73.51 \\
\hline A13 x IS 14446 & 113.56 & 14.32 & 10.73 & 74.40 \\
\hline
\end{tabular}

Table 5. Mean comparisons among 36 sweet sorghum cultivars, lines and hybrids regarding stem yield, Brix , Sucrose and purity (Almodares and Sepahi, 1996).

Besides having rapid growth, high sugar accumulation (Almodares and Sepahi, 1996), and biomass production potential (Almodares et al., 1994), sweet sorghum has wider 
adaptability (Reddy et al., 2005). Many factors could increase biomass in sweet sorghum such as: fertilizer (Almodares et al., 2006, 2008d, 2009, 2010), irrigation regimes (Almodares \& Sharif, 2007), cultivars (Table 5), plant population density (Solymani et al., 2010), planting dates (Almodares et al., 1997) (Table 6), harvesting stages (Almodares et al., 2010), climatic conditions, etc.

Almodares et al. (2006) reported that application of nitrogen-fertilizer siginficantly increased leaf area, leaf dry weight, stem dry weight, total dry weight, paincle dry weight and paincle dry length of sweet sorghum cultivars. Almodares et al., 2010 reported that among nitrogen treatments, application of $100 \mathrm{~kg}$ ha- 1 urea at planting and $200 \mathrm{~kg}$ ha- 1 urea at 4 leaf stage had the highest aconitic acid (0.26\%) and invert sugar (3.44\%).

\begin{tabular}{lllll}
\hline Cultivars & \multicolumn{2}{l}{ Stalk yield t/ha } & sucrose yield $\mathrm{t} / \mathrm{ha}$ & \\
& May 5 & june 5 & May 5 & June 5 \\
\hline Soave & $46.1 \mathrm{~cd}$ & $33.0 \mathrm{de}$ & $5.7 \mathrm{~cd}$ & $4.2 \mathrm{~b}$ \\
Brandes & $54.4 \mathrm{cc}$ & $49.8 \mathrm{~b}$ & $3.7 \mathrm{ef}$ & $4.2 \mathrm{~b}$ \\
Theis & $56.7 \mathrm{bc}$ & $56.8 \mathrm{ab}$ & $2.8 \mathrm{fg}$ & $2.3 \mathrm{~cd}$ \\
MN1500 & $66.6 \mathrm{ab}$ & $49.7 \mathrm{~b}$ & $6.5 \mathrm{bc}$ & $4.2 \mathrm{~b}$ \\
Wray & $71.8 \mathrm{a}$ & $63.1 \mathrm{a}$ & $7.2 \mathrm{ab}$ & $5.3 \mathrm{ab}$ \\
Keller & $68.7 \mathrm{a}$ & $54.6 \mathrm{ab}$ & $8.5 \mathrm{a}$ & $5.7 \mathrm{a}$ \\
Dale & $75.5 \mathrm{a}$ & $47.7 \mathrm{bc}$ & $4.8 \mathrm{de}$ & $2.1 \mathrm{~cd}$ \\
Vespa & $51.7 \mathrm{c}$ & $42.4 \mathrm{~cd}$ & $6.1 \mathrm{bcd}$ & $5.2 \mathrm{ab}$ \\
NK326 & $35.5 \mathrm{~d}$ & $17.8 \mathrm{~d}$ & $3.0 \mathrm{f}$ & $0.7 \mathrm{c}$ \\
NK300 & $23.8 \mathrm{e}$ & $25.2 \mathrm{e}$ & $1.5 \mathrm{~g}$ & $1.0 \mathrm{~d}$ \\
\hline
\end{tabular}

* Mean comparisons were made using Student Newman Keuls' test. Means with the same letter (a, b, ...) within a column are not significantly difference at $5 \%$ level.

Table 6. Mean comparisons* between the ten sweet sorghum cultivars for the two planting dates and two characteristics of economical importance (Almodares et al., 1994).

\subsubsection{Low water requirement}

In the semiarid regions, water and salinity stresses are increasingly becoming primary limiting environmental conditions which restrict successful establishment of crops. Sorghum is tolerant of low input levels and essentially for areas that receive too little rainfall for most other grains (Table 7). Increased demand for limited fresh water supplies, increasing use of marginal farmland, and global climatic trends, all suggest that dry land crops such as sorghum will be of growing importance to feed the world's expanding 
populations. Generally lower water demands for sorghum than maize, versus their equal ethanol yields, suggests that sorghum will be of growing importance in meeting grain-based biofuels needs. In many tropical and temperate countries where sugarcane cannot be grown, a growing interest is being focused on the potential of sweet sorghum to produce bioethanol feed stocks (Avant, 2008) specially that salinity and drought tolerance are major features of sweet sorghum with low water requirements for high yields. One of the main reactions to drought stress is closing of stomata. The C4 plant such as sweet sorghum, in opposite to the C3, are able to utilize very low concentration of carbon dioxide which enables them to assimilate $\mathrm{CO}_{2}$ even during considerable stomatal closure (El Bassaru, 1998). This might be one of the probable reasons for the difference in resistance to stress between both plant groups. Photosynthesis is a complex process; therefore, it is possible that a number of elements in the $\mathrm{C} 3$ and the $\mathrm{C} 4$ may differ in resistance to drought.

\begin{tabular}{|c|c|c|c|}
\hline & Sugarcane & Sugar beet & Sweet sorghum \\
\hline Crop duration & About 7 months & About $5-6$ months & About 4 months. \\
\hline Growing season & Only one season & Only one season & $\begin{array}{l}\text { One season in temperate and } \\
\text { two or three seasons in } \\
\text { tropical area. }\end{array}$ \\
\hline Soil requirement & Grows well in drain soil & $\begin{array}{l}\text { Grows well in sandy loam; also } \\
\text { tolerates alkalinity }\end{array}$ & All types of drained soil. \\
\hline Water management & $36000 \mathrm{~m}^{3} / \mathrm{h}$ & $18000 \mathrm{~m}^{3} / \mathrm{h}$ & $12000 \mathrm{~m}^{3} / \mathrm{h}$ \\
\hline Crop management & $\begin{array}{l}\text { Requires good } \\
\text { management }\end{array}$ & $\begin{array}{l}\text { Greater fertilizer requirement; } \\
\text { requires moderate management }\end{array}$ & $\begin{array}{l}\text { Little fertilizer required; less } \\
\text { pest and disease complex; } \\
\text { easy management. }\end{array}$ \\
\hline Yield per ha & $70-80$ tons & $30-40$ tons & $54-69$ tons. \\
\hline Sugar content on weight basis & $10-12 \%$ & $15-18 \%$ & $7-12 \%$. \\
\hline Sugar yield & $7-8$ tons/ha & $5-6$ tons/ha & $6-8$ tons/ha. \\
\hline $\begin{array}{l}\text { Ethanol production directly } \\
\text { from juice }\end{array}$ & $3000-5000 \mathrm{~L} / \mathrm{ha}$ & $5000-6000 \mathrm{~L} / \mathrm{ha}$ & $3000 \mathrm{~L} / \mathrm{ha}$. \\
\hline Harvesting & Mechanical harvested & Very simple; normally manual & $\begin{array}{l}\text { Very simple; both manual and } \\
\text { through mechanical } \\
\text { harvested. }\end{array}$ \\
\hline
\end{tabular}

Table 7. Comparison of Sugarcane, Sugar Beet, and Sweet Sorghum in Iran (Almodares \& Hadi, 2009).

\subsection{Biofuel advantages}

\subsubsection{Bioethanol production from sweet sorghum}

Sweet sorghum is a crop for producing energy which not only produce food, but also energy, feed and fiber (Almodares \& Hadi, 2009). The chief sugars present in sorghum are monosaccharides: glucose and fructose, and disaccharides: sucrose. Fermentable carbohydrates in sweet sorghum stalks comprise approximately $80 \%$ soluble sugars and $20 \%$ starch. To optimize production of ethanol from sweet sorghum grain requires both liquefying and saccharifying enzymes (Rooney and Waniska, 2000). Therefore, it seems that using carbohydrates in the stalk (sucrose and invert sugar) is suitable for ethanol production for biofuel production because these carbohydrates are easily converted to ethanol (Fig 2). Although, ethanol can be produced from sweet sorghum grain (Fig. 2) but it needs more process for converting it's starch to glucose that later will be converted to ethanol (Jacques et al., 1999). In addition, the produced baggase after juice extraction can be used for ethanol production (Jacques et al., 1999) or animal feed. However, presently it is not economically feasible to produce ethanol from sweet sorghum baggase (Drapcho et al., 2008). 


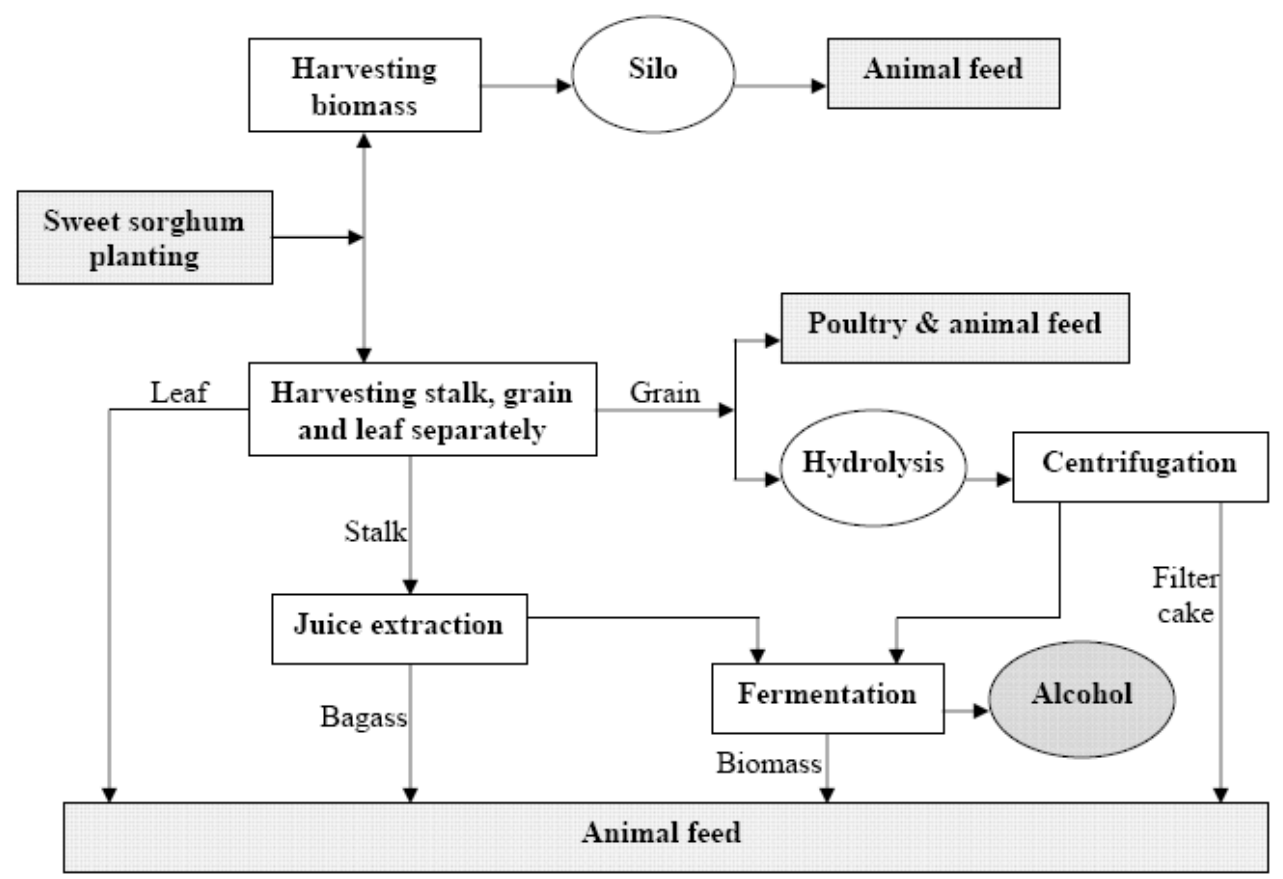

Fig. 2. Proposed layout for ethanol production and by-product from sweet sorghum (Almodares \& Hadi, 2009).

\subsubsection{The important of ethanol in biofuel}

One method to reduce air pollution is to oxygenated fuel for vehicles. MTBE (Methyl tertbutyl ether) is a member of a group of chemicals commonly known as fuel oxygenates (Fischer et al., 2005). It is a fuel additive to raise the octane number. But it is very soluble in water and it is a possible human carcinogenic (Belpoggi et al., 1995). Thereby, it should be substituted for other oxygenated substances to increase the octane number of the fuel. Presently, ethanol as an oxygenated biomass fuel is considered as a predominant alternative to MTBE for its biodegradable, low toxicity, persistence and regenerative characteristic (Cassada et al., 2000). In most countries, gasoline supply is an ethanol blend, and the importance of ethanol use is expected to increase as more health issues are related to air quality. Ethanol may be produced from many high energy crops such as sweet sorghum, corn, wheat, barely, sugar cane, sugar beet, cassava, sweet potato and etc (Drapcho et al., 2008). Like most biofuel crops, sweet sorghum has the potential to reduce carbon emissions. Therefore, it seems that sweet sorghum is the most suitable plant for biofuel production than other crops under hot and dry climatic conditions. In addition, possible use of bagasse as a by-product of sweet sorghum include: burning to provide heat energy, paper or fiber board manufacturing, silage for animal feed or fiber for ethanol production. However, since 
sweet sorghum is at a relatively early stage of its development, continued research was needed to obtain better genetic material and match local agro-economic conditions. The challenge is to harvest the crop, separate it into juice and fiber, and utilize each constituent for year-round production of ethanol.

Sweet sorghum juice is assumed to be converted to ethanol at $85 \%$ theoretical, or 54.4 liter ethanol per $100 \mathrm{~kg}$ fresh stalk yield. Potential ethanol yield from the fiber is more difficult to predict (Rains et al., 1993). The emerging enzymatic hydrolysis technology has not been proven on a commercial scale (Taherzadeh and Karimi, 2008). One ton of corn grain produces $387 \mathrm{~L}$ of 182 proof alcohol while the same amount of sorghum grain produces 372 L (Smith and Frederiksen, 2000). Sorghum is used extensively for alcohol production (Gnansounou et al., 2005), where it is significantly lower in price than corn or wheat (Smith and Frederiksen, 2000). The commercial technology required to ferment sweet sorghum biomass into alcohol has been reported in china (Gnansounou et al., 2005). One ton of sweet sorghum stalks has the potential to yield $74 \mathrm{~L}$ of 200- proof alcohol (Smith and Frederiksen, 2000). Therefore, it seems that because ethanol can be produced from both stalk and grain of sweet sorghum (Fig. 2), so it is the most suitable crop for ethanol production using for biofuel comparing to other crops such as corn or sugarcane.

\section{Food and feed}

Sorghum is an important food cereal in many parts of worldwide. According to the U.S. National Sorghum Producers Association (2006), approximately 50\% of the world production of sorghum grain is used as human food. Sorghum grain is a staple diet in Africa, the Middle East, Asia and Central America where its processed grain may be consumed in many forms including porridge, steam-cooked product, tortillas, baked goods, or as a beverage (CGIAR, 2009). China and India account for almost all of the food use of sorghum in Asia, in other parts of the world, sorghum grain is used mainly as an animal feed. It has the distinct advantage (compared to other major cereals) of being drought-resistant and many subsistence farmers in these regions cultivate sorghum as a staple food crop for consumption at home (Murty and Kumar, 1995). Therefore sorghum acts as a principal source of energy, protein, vitamins and minerals for millions of the poorest people living in these regions (Klopfenstein and Hoseney, 1995). The improvement of sorghum nutrient availability is critical for food security. Cereal scientists and sorghum food processors are thus faced with the challenge of identifying the factors that adversely affect, and developing processing procedures that improve sorghum protein digestibility. Most parts of the sorghum plant are used as animal feed. Growing sorghum may be grazed, or the aerial parts of the plant may be ensiled or dried and fed as stover or silage for ruminant animals. Whole sorghum grain is cracked, ground, or steam flaked and fed to poultry, swine, dairy and beef cattle as a source of energy. Crop residues are a major animal feed resource in many crop-livestock farming systems. They are very useful in ameliorating the problem of inadequacy of feeds for ruminant livestock during the dry season. Although useful as dry season feeds, crop residues, particularly those of cereal origin, are low in protein and energy content (Agyemang et al., 1998). The stover of sorghum also is used as fodder for animals. The nutrient composition of sorghum grain is presented in Table 8. 


\begin{tabular}{|c|c|c|}
\hline Measurement & $\mathrm{NRC}^{1}$ & $\begin{array}{c}\text { Range of } \\
\text { mean values }\end{array}$ \\
\hline Moisture, \% & $10.0-12.5$ & $9.2-12.5$ \\
\hline \multicolumn{3}{|c|}{$\% D M^{2}$} \\
\hline Crude Protein $^{3}$ & $10.1-12.6$ & $10.1-15.6$ \\
\hline Total $\mathrm{fat}^{4}$ & $3.0-3.3$ & $0.8-4.3$ \\
\hline Ash & $1.9-2.0$ & $1.5-3.3$ \\
\hline Nitrogen-free extract (NFE) ${ }^{3}$ & & $70.8-84.9$ \\
\hline Crude Fibre & $2.6-3.0$ & $1.7-6.9$ \\
\hline $\mathrm{NDF}^{6}$ & $10.9-23.0$ & $10.9-23.0$ \\
\hline $\mathrm{ADF}^{7}$ & $5.0-9.3$ & $5.0-9.0$ \\
\hline
\end{tabular}

${ }^{1}$ NRC- Nutrient Requirements for Poultry

${ }^{2} \mathrm{DM}=$ Dry mater

${ }^{3}$ Crude protein $=$ Nitrogen $\times 6.25$

${ }^{4}$ Total fat as measured by ether extract

${ }^{5} \mathrm{NFE}=100-($ ash + ether extract + crude protein + crude fibre $)$

${ }^{6}$ Neutral detergent fibre

${ }^{7}$ Acid detergent fibre

Table 8. Proximate analysis of S. bicolor grain (dry matter basis) (Quotation from OECD, 2010)

\subsection{By-products of sorghum processing}

The by-product of sorghum ethanol production is distillers' grains. Table 9 presents the available nutritional information for wet and dry sorghum distillers' grains, and dry grains plus solubles. Distiller's dried grains with solubles contain all fermentation residues, including yeast, remaining after ethanol is removed by distillation (Shurson, 2009).

\begin{tabular}{|c|c|c|c|}
\hline & $\begin{array}{c}\text { Wet } \\
\text { distiller's' }\end{array}$ & $\begin{array}{c}\text { Dry } \\
\text { distillers' }\end{array}$ & $\begin{array}{c}\text { Dry distillers' } \\
+ \text { solubles }\end{array}$ \\
\hline DM, $\%^{1}$ & $23.5-35.3$ & 91.4 & 91.4 \\
\hline \multicolumn{4}{|c|}{ (\% DM basis) } \\
\hline Crude Protein & $31.2-31.6$ & 32.9 & 31.4 \\
\hline Ash & 2.5 & & \\
\hline Total fat & $11.3-13.3$ & 13.0 & 11.8 \\
\hline $\mathrm{ADF}^{2}$ & 28.5 & 28.4 & \\
\hline $\mathrm{NDF}^{3}$ & $41.3-45.4$ & 45.8 & 51.1 \\
\hline $\mathrm{NSC}^{4}$ & 9.2 & 3.3 & \\
\hline Starch & 10.2 & & 7.4 \\
\hline
\end{tabular}

${ }^{1}$ Dry matter; ${ }^{2}$ Acid detergent fibre ; ${ }^{3}$ Neutral detergent fibre ; ${ }^{4}$ Non-structural carbohydrate

Table 9. Nutrient composition of sorghum distillers' grains (Quotation from OECD, 2010).

\section{Conclusion}

It is clear that biomass production for biofuel from sweet sorghum is the best choice to be implement under hot and dry climatic conditions regarding both economic and environmental considerations. Because, sweet sorghum has higher tolerance to drought 
(Tesso et al., 2005), water logging , and salt (Almodares et al., 2008a, 2008b), alkali, and aluminum soils; It may be harvested 3-4 month after planting and planted 1-2 times a year (in tropical areas); Its energy output/fossil energy input is higher than sugarcane, sugar beet, corn, wheat and etc... specially in temperate areas; It is more water use efficient $(1 / 3$ of water used by sugarcane at equal sugar production); Its production can be completely mechanized and Its bagasse has higher nutritional value than the bagasse from sugarcane, when used for animal feeding. Also, by implementing agricultural practices such as adequate water and fertilizers, suitable cultivars or hybrids, crop rotation, pest management and etc... can increase productivity with focus on biofuel production from its biomass (Reddy et al., 2005). In addition, sweet sorghum has high amount of sucrose (Almodares and Sepahi, 1996) and invert sugar (Almodares et al., 2008c) which are easily converted to ethanol (Prasad et al., 2007). Therefore, it seems that sweet sorghum biomass is the most suitable raw material for biofuel production in arid regions of the world. This awareness should push government of the countries with such climatic conditions to promote the development of projects for fuel ethanol production from sweet sorghum biomass.

\section{References}

Aharon, GS., Apse ,MP., Duan, SL.,Hua, XJ., Blumwald, E. (2003)Characterization of a family of vacuolar $\mathrm{Na}+\mathrm{H}+$ antiporters in Arabidopsis thaliana. Plant Soil;253:245-256.

Ahloowalia, BS.(2004) Global impact of mutation-derived varieties. Uphytica 135: 187-204.

Ali, Y., Aslam Z., Ashraf M. Y and Tahir G. R (2004). Effect of salinity on chlorophyll concentration, leaf area, yield and yield components of rice genotypes grown under saline environment. International Journal of Environmental Science and Technology, 1( 3):221-225.

Almodares , A., Hadi , M. R. and Dosti B.(2008a). The effects of salt stress on growth parameters and carbohydrates contents in sweet sorghum. Research Journal of environmental science, 2 (4):298-304.

Almodares ,A,. Sepahi ,A . (1996) Comparison among sweet sorghum cultivars, lines and hybrids for sugar production. Ann. Plant Physiol. 10: 50-55.

Almodares ,A,. Sepahi, A., Dalilitajary ,H., Gavami ,R. (1994) Effect of phenological stages on biomass and carbohydrate contents of sweet sorghum cultivars Ann. Plant Physiol. 8: 42-48.

Almodares ,A., Sharif ,ME. (2007) Effects of irrigation water qualities on biomass and sugar contents of sugar beet and sweet sorghum cultivars. J. Environ. Biol. 28: 213-218.

Almodares ,A., Sharif, ME. (2005) Effect of water quality on yield of sugar beet and sweet sorghum. J. Environ. Biol. 26: 487-493.

Almodares, A and Hadi , M. R.(2009). Production of Bioethanol from Sweet Sorghum - A Review. African Journal of Agricultural Research Vol. 4 (9), pp. 772 - 780, September, 2009

Almodares, A., Taheri, R., Hadi, MR., Fathi , M . (2006). The Effect of Nitrogen and Potassium Fertilizers on the Growth Parameters and the Yield Components of Two Sweet Sorghum Cultivars. Pakistan. Biol. Sci. 9: 2350-2353

Almodares, A., Hadi, MR., Ahmadpour, H .(2008b) Sorghum stem yield and soluble cabohdrates under phonological stages and salinity levels Afircan J. Biotech. 7: 4051-4055.

Almodares, A., Hadi, MR., Dosti , B. (2007a) Effects of Salt Stress on Germination Percentage and Seedling Growth in Sweet Sorghum Cultivars. J. Biol. Sci. 7: 1492-1495. 
Almodares, A., Jafarinia M., \& Hadi, M. R. (2009) The Effects of Nitrogen Fertilizer on Chemical Compositions in Corn and Sweet Sorghum. American-Eurasian J. Agric. \& Environ. Sci., 6 (4): 441-446.

Almodares, A., Ranjbar M. and Hadi, M. R (2010) The Effects of Nitrogen Treatments and Harvesting Stages on the Aconitic Acid, Invert Sugar and Fiber in Sweet Sorghum Cultivars. Journal of Environmental Biology 31(6) 1001-1005.

Almodares, A., Sepahi, A., Shirvani, M .(1997) The effects of planting date and genotype on carbohydrate production from sweet sorghum in the south of Iran. Ann. Plant Physiol. 11: 1-5.

Almodares, A., Taheri, R., Adeli, S .(2008c) Stalk yield and carbohydrate composition of sweet sorghum [Sorghum bicolor (L.) Moench] cultivars and lines at different growth stages. J. Malesian Appl. Biol. 37: 31-36.

Almodares, A., Taheri, R., Chung, M., Fathi, M .(2008d). The effect of nitrogen and potassium fertilizers on growth parameters and carbohydrate content of sweet sorghum cultivars. J. Environ. Biol. 29: 849-852

Almodares, A., Taheri, R., Safavi, V.(2008e) Sorghum, Botany, Agronomy and Biotechnology, Jahad Daneshgahi of University of Isfafan, Isfahan.

Asch, F., Dingkuhn, M., Drffling, K. and Miezan, K.( 2000). Leaf K/Na ratio predicts salinity induced yield loss in irrigated rice. Euphytica, 113: 109-118.

Ashraf, M. (1994). Breeding for salinity tolerance in plants. Critical Review in Plant Science, 13: $17-42$.

Ashraf, M., Harris PJC (2004). Potential biochemical indicators of salinity tolerance in Plants. Plant Sci. 166(1): 3-16.

Avant,B (2008).Hightonnagededicatedenergycrops.In:ProceedingsWorld Biofuels markets Congress, Bruxelles (BE), 12-14.

Ayers, R.S., and D.W. Westcot (1989). Water quality for agriculture. Irrigation and Drainage Paper No. 29, Rev. 1, FAO, Rome.

Azhar, F.M \& McNeilly, T. (1988).The genetic basis of variation for salt tolerance in Sorghum bicolor (L.) Moench, seedlings. Plant Breed 101: 114-121

Belpoggi ,F., Soffritti ,M., Maltoni, C. (1995) Methyl tertiary-butyl ether (MTBE) - A gasoline additive - causes testicular and lymphohaematopoetic cancers in rats. Toxicol. Ind. Health 11: 119-149.

Beta, T., Rooney, L., and Taylor, J (2000). Effect of chemical conditioning on the milling of high-tannin sorghum. Journal of the Science of Food and Agriculture. 80:2216-2222.

Blokhina, O., Virolainen ,E., Fagerstedt, KV. (2003) Antioxidants, oxidative damage and oxygen deprivation stress: a review. Ann Bot (Lond) 91: 179-194

Boursier, P., Lauchli,A (1990). Growth responses and mineral nutrient relations of salt stressed sorghum. Crop Sci. 30, 1226-1233.

Brady, N. C. \& Weil R. R (2002). The Nature and Properties of Soils. Thirteenth Edition, Pearson Education Inc, USA, 823p.

Cassada, DA., Zhang, Y., Snow ,DD., Spalding ,RF. (2000) Trace analysis of ethanol, MTBE, and related oxygenate compounds in water using solid-phase microextraction and gas chromatography/mass spectrometry. Analy. Chem. 72: 4654-4658.

CGIAR (Consultative Group on International Agricultural Research) (2009) website http://www.cgiar.org/.

Chhipa, B.R and Lal P.(1995) Na/K ratios as the basis of salt tolerance in wheat. Aust. J. Agric. Res. 46, pp. 533-539 
Colmer, T. D., Epstein, E. and Dvorak, J (1995). Differential solute regulation in leaf blades of various ages in salt sensitive wheat and salt tolerant wheat $\times$ Lophopyrum elongatum (Host) love amphiploid. Plant Physiology, 108: 1715-1724.

Cosentino, S.L (1996) .Crop physiology of sweet sorghum ( Sorghum bicolor (L.)Moench).In: Proceedings of First European Seminaron Sorghum for Energy and Industry, 1-3 April, Toulose, France, pp. 30-41.

Cramer, G., Laughli, A and Epstein, E. (1986) Effects of $\mathrm{NaCl}$ and $\mathrm{CaCl} 2$ on Ion Activities in Complex Nutrient Solutions and Root Growth of Cotton'Plant .Physiol. 81, 792-797

Drapcho ,CM., Nhuan, NP., Walker, TH. (2008) Biofuels Engineering Process Technology, The McGraw-Hill companies, Inc, USA

Duodu, K.G., Taylor ,J.R.N., Belton ,P.S., Hamaker ,B.R.(2003) Factors affecting sorghum protein digestibility. Journal of Cereal Science 38 (2003) 117-131

El-Sayed, H., El-Haddad, M and. Oleary,J.W (1994).Effect of salinity and K/Na ratio of irrigation water on growth and solute content of Atriplex amnicola and Sorghum bicolor. Irrig. Sci., 14: 127-133.

FAO/AGL.; [Online] Available http://www.fao.orglag/agl/agll/spush/topic?.htm.; November, 2000.

Fischer, A., Oehm , C., Selle, M., Werner, P. (2005) Biotic and abiotic transformations of methyl tertiary butyl ether (MTBE). Environ. Sci. Pollut. Res. Int. 12: 381-386.

Ghassemi, F., Jakeman, A.J., and Nix, H.A (1995), Salinisation of land and waterresources: Human causes, extent, management and case studies: Wallingford,UK, CAB International, 544

Gill, P.K., Sharma A. D.., Singh P., Bhullar S. S (2001). Effect of various abiotic stresses on the growth, soluble sugars and water relations of sorghum seedlings grown in light and darkness. Bulg. J. Plant Physiol., 27(1-2): 72-84.

Gill,P.K.,Sharma,A.D.,Singh,P.,Bhullar,S.S (2003).Changes in germination, growth and soluble sugar contents of Sorghum bicolor (L.) Moench seeds under various abiotic stresses. Plant Growth Regul. 40, 157-162.

Goyal , S., Chander ,K.. Mundra ,M. C., Kapoor, K. K. (1999) Influence of inorganic fertilizers and organic amendments on soil organic matter and soil microbial properties under tropical conditions Biol Fertil Soils 29 :196-200

Gupta, A. K., Sharma S. K., Sindhu S. S. and Yadav S (2003). Effect of soil salinity on mineral and proline contents of chrysanthemum. Haryana Journal of Horticultural Sciences, 32(3/4): 224-227

Hasegawa,P.M.,Bressan,R.A.,Zhu,J.-K.,Bohnert,H.(2000). PlantCellular and molecular responses to high salinity. Ann. Rev. Plant Physiol. PlantMol.Biol.51,463-499.

Ibrahim, A. H. (2004).Efficacy of exogenous glycine betaine application on sorghum plants grown under salinity stress. Acta Botanica Hungarica, 43(3-4): 307-318

ICRISAT (International Crops Research Institute for the Semi-Arid Tropics) (2009), website http://www.icrisat.org/.

Igartua, E., M.P. Gracia and J.M. Lasa, (1994). Characterization and genetic control of germination-emergence responses of grain sorghum to salinity. Euphytica, 76: 185-193.

Jacques,K., Lyons ,TP., Kelsall ,DR .(1999) The Alcohol Textbook.3rd Edition. 388pp.

Juan, M., Rivero R. M., Romero L and Ruiz J. M (2005). Evaluation of some nutritional and biochemical indicators in selecting salt-resistant tomato cultivars. Environmental and Experimental of Botany, 54(3): 193-201.

Kinfemichael, G and Melkamu,G.( 2008). Response of some lowland growing sorghum (Sorghum bicolor L. Moench) accessions to salt stress during germination and seedling growth. African Journal of Agricultural Research Vol. 3 (1), pp. 044-048. 
Klopfenstein,C.F.,Hoseney,R.C(1995).Nutritionalpropertiesofsorghum and the millets. In: Dendy, D.A.V., (Ed.), Sorghum and Millets: Chemistry and Technology,American Association of Cereal Chemists, St Paul, MN, pp. 125-168.

Krishnamurthy, L., Serraj R., Hash C. T., Dakheel A. J and Reddy B.V. S (2007). Screening sorghum genotypes for salinity tolerant biomass production. Euphytica, 156 (1-2):15-24.

Lacerda, C. F., Cambraia J., Oliva M. A., Ruiz H. A (2005). Changes in growth and in solute concentrations in sorghum leaves and roots during salt stress recovery. Environmental and Experimental Botany, 54: 69-76.

Lacerda, CF., Cambraia, J., Oliva,MA., Ruiz, HA. (2001) Plant growth and solute accumulation and distribution in two sorghum genotypes, under $\mathrm{NaCl}$ stress. Rev. Bras. Fisiol.Veg. 13:270-284.

Maiti,R.K.,Ibarra,M.R.,Sandoval,N (1994).Genotypic variability in glossy sorghum lines for resistance to drought, salinity and temperature stress at the seedling stage. J. Plant Physiol. 143,241-244.

McKersie, B.D. and Leshem, Y.Y. (1994). Stress and Stress Coping in Cultivated Plants. Kluwer Academic Publishers, Dordrecht, Netherlands

Meneguzzo, S., Navari-Izzo, F. and Izzo, R (2000). NaCl effects on water relations and accumulation of minerals in shoots, roots and cell sap of wheat seedling. Journal of Plant Physiology, 156: 711-716.

Mittler, R (2002). Oxidative stress, antioxidants and stress tolerance. Trends Plant Sci. 7, 405-410.

Munns, R., 2002. Comparative physiology of salt and water stress. Plant Cell and Environment, 25: 239- 250.

Munns,R., Schachtman ,D.P. \& Condon ,A.G. (1995) The significance of a two-phase growth response to salinity in wheat and barley. Australian Journal of Plant Physiology 22, 561-569.

Murty, D.S., Kumar, K.A (1995).Traditional uses of sorghum and millets.In: Dendy, D.A.V., (Ed.), Sorghum and Millets: Chemistry and Technology, American Association of Cereal Chemists, St Paul, MN, pp. 185-221.

Netondo, G. W, Onyango J. C and Beck E(2004). Sorghum and Salinity: II. Gas Exchange and Chlorophyll Fluorescence of Sorghum under Salt Stress. Crop Sci. 44:806-811

OECD (Organisation de Coopération et de Développement Économiques) 2010. Consensus ocument on Compositional Considerations for New Varieties of GRAIN SORGHUM [Sorghum bicolor (L.) Moench]: Key Food and Feed Nutrients and Anti-nutrients (http://www.oecd.org/ehs/).

Pardossi, A. , Malorgio, F. , Oriolo, D. , Gucci, R. , Serra, G. and Tognoni, F(1988) Water relations and osmotic adjustment in Apium graveolens during long-term $\mathrm{NaCl}$ stress and subsequent relief. Physiol. Plant. 102 , pp. 369-376.

Prado,F.E., Boero,C., Gallardo,M., Gonzalez, J.A (2000). Effect of $\mathrm{NaCl}$ on germination, growth and soluble sugar content in Chenopodium quinoa willd seeds. Bot. Bull.Acad. Sin. 41, 27-34.

Qureshi, MS., Richards, B., Hay, A., Tsai, C., McBride, M., Baveye, P., Steenhuis,T. (2003). Effect of microbial activity on trace element release from sewage sludge, Environmental Science \& Technology, Vol. 37, No. 15, pp. 3361-3366

Renault, S., Clare, C., Franklin, JA., Zwiazek ,JJ. (2001) Effects of $\mathrm{NaCl}$ and $\mathrm{Na}_{2} \mathrm{SO}_{4}$ on redosier dogwood (Cornus stolonifera Michx) seedlings. Plant Soil 233: 261-268DOI

Richards, KD., snowden, KC., Gardner, RC. (1994) wali6 and wali7: genes induced by aluminum in wheat (Triticum aestium L.) roots. Plant Physiol 105:1455-1456.

Rivelli, A.R., Lovelli, S., Perniola, M (2002). Effects of salinity on gas exchange, water relations and growth of sun flower(Helianthusannuus). Funct. Plant Biol. 29, 1405-1415. 
Rogers, M.E., Noble, C.L( 1992) Variation in growth and ion accumulation between two selected populations of Trifolium repens L. differing in salt tolerance. - Plant Soil. 146: 131-136,

Samadani, B., B. Kholdbarin. and A. Almodares.(1994). Salt tolerance of sweet sorghum cultivars and their mechanisms. M. Sc. thesis in biology (plant physiology). Shiraz University - Iran, pages 45, 60, 82.

Saneoka, H., Ishiguro, S and Moghaieb , E.( 2001 )Effect of salinity and abscisic acid on accumulation of glycinebetaine and betaine aldehyde dehydrogenase mRNA in Sorghum leaves (Sorghum bicolor).Journal of Plant Physiology Volume 158, Issue 7, Pages 853-859.

Santa-Maria, G. E.; Epstein, E ( 2001) Potassium/sodium selectivity in wheat and amphiploid cross wheat $\times$ Lophopyrum elongatum. Plant Sci. 160: 523-534.

Shalata,A., Tal ,M.(1998).The effect of salt stress on lipid peroxidation and antioxidants in the leaf of the cultivated tomato and its wild salt-tolerant relative Lycopersicon pennellii. Physiologia Plantarum104, 169-174

Shurson, J. (2009), Distillers Grains By-products in Livestock and Poultry Feeds, Overview: Distiller's Dried Grains with Solubles, Dept. of Animal Science, College of Food, Agriculture and Natural Resource Science, University of Minnesota, St. Paul, MN, available online at http:/ / www.ddgs.umn.edu/overview.htm.

Smith ,CW., Frederiksen ,RA (Eds.) (2000) Sorghum: Origin, history, technology, and production, John Wiley and Sons, New York Gnansounou E, Dauriat A, Wyman CE (2005) Refining sweet sorghum to ethanol and sugar: economic trade-offs in the context of North China. Bioresource Technol. 96: 985-1002.

Smith, CW., Frederiksen, RA (Eds.) (2000) Sorghum: Origin, history, technology, and production, John Wiley and Sons, New York.

Solymani, A., A.Almodares and L. Naranjani. (2010). Effects of plant populations on stalk yields and sucrose content of two sweet sorghum cultivars. Iranian j. Field Crop Res. 8 (3):455-464.

Sudhir, P., Murthy S. D (2004). Effects of salt stress on basic processes of photosynthesis. photosynthetica ,42(4):481-486.

Sunseri, F ., Palazzo ,D., Montemurro, N and Monte murro, F. (2002). Salinity tolerance in sweet sorghum. ( Sorghum bicolor L. Manch). Field performance under salt stress. Ital. J. Agron., 2(2): 111-1

Szabolcs, I .(1994). Soil salinization. In: M. Pessarakli, Editor, Handbook of Plant Crop Stress, Marcel Dekker, New York, pp. 3-11.

Taherzadeh, MJ., Karimi, K .(2008) Bioethanol: Market and Production Processes. In: Biofuels Refining and Performance (Ed. A Nag). The Mc Graw- Hill, USA Rains GC, Cundiff JS, Welbaum GE (1993) Sweet sorghum for a piedmont ethanol industry. In: New crops (Eds. J Janick \& JE Simon). Wiley New York.

Tesso, TT., Claflin, LE., Tuinstra ,MR.(2005) Analysis of Stalk Rot Resistance and Genetic Diversity among Drought Tolerant Sorghum Genotypes. Crop Sci. 45: 645-652.

U.S. Grains Council (2008), Sorghum, Washington DC., available online at http:/ / www.grains.org/sorghum.

U.S. National Sorghum Producers Association (2006), website http://www.sorghumgrowers.com/.

Wichelns, D., and J.D. Oster (2006). Sustainable irrigation is necessary and achievable, but direct costs and environmental impacts can be substantial. Agricultural Water Management, 86: 114-27.

Zhu, J. (2001) Plant salt tolerance. Trends in Plant Science 6, 66-71 


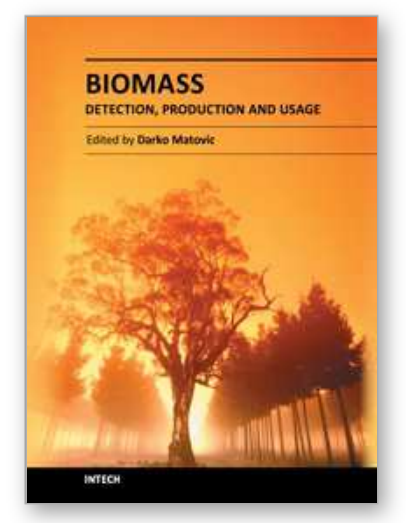

\author{
Biomass - Detection, Production and Usage \\ Edited by Dr. Darko Matovic
}

ISBN 978-953-307-492-4

Hard cover, 496 pages

Publisher InTech

Published online 09, September, 2011

Published in print edition September, 2011

Biomass has been an intimate companion of humans from the dawn of civilization to the present. Its use as food, energy source, body cover and as construction material established the key areas of biomass usage that extend to this day. Given the complexities of biomass as a source of multiple end products, this volume sheds new light to the whole spectrum of biomass related topics by highlighting the new and reviewing the existing methods of its detection, production and usage. We hope that the readers will find valuable information and exciting new material in its chapters.

\title{
How to reference
}

In order to correctly reference this scholarly work, feel free to copy and paste the following:

A. Almodares, M. R. Hadi and Z. Akhavan Kharazian (2011). Sweet Sorghum: Salt Tolerance and High Biomass Sugar Crop, Biomass - Detection, Production and Usage, Dr. Darko Matovic (Ed.), ISBN: 978-953307-492-4, InTech, Available from: http://www.intechopen.com/books/biomass-detection-production-andusage/sweet-sorghum-salt-tolerance-and-high-biomass-sugar-crop

\section{INTECH}

open science | open minds

\section{InTech Europe}

University Campus STeP Ri

Slavka Krautzeka 83/A

51000 Rijeka, Croatia

Phone: +385 (51) 770447

Fax: +385 (51) 686166

www.intechopen.com

\section{InTech China}

Unit 405, Office Block, Hotel Equatorial Shanghai

No.65, Yan An Road (West), Shanghai, 200040, China

中国上海市延安西路65号上海国际贵都大饭店办公楼405单元

Phone: +86-21-62489820

Fax: +86-21-62489821 
(C) 2011 The Author(s). Licensee IntechOpen. This chapter is distributed under the terms of the Creative Commons Attribution-NonCommercialShareAlike-3.0 License, which permits use, distribution and reproduction for non-commercial purposes, provided the original is properly cited and derivative works building on this content are distributed under the same license. 